\title{
Influence of Teacher Competence on Mathematics Performance in KCSE Examinations Among Public Schools in Nyatike Subcounty, Migori County Kenya
}

\author{
Kenaz Rakiro Ochieng ${ }^{1}$, Paul Kiplagat ${ }^{2}$, Stephen Nyongesa ${ }^{3}$ \\ ${ }^{1}$ Department of Education Planning and Administration, Mount Kenya University, Nairobi, Kenya \\ ${ }^{2}$ Department of Education, Mount Kenya University, Nairobi, Kenya \\ ${ }^{3}$ Department of Education,Kisii University, Kisii, Kenya
}

Email address:

rakiroz@gmail.com (K. R. Ochieng)

\section{To cite this article:}

Kenaz Rakiro Ochieng, Paul Kiplagat, Stephen Nyongesa. Influence of Teacher Competence on Mathematics Performance in KCSE Examinations Among Public Schools in Nyatike Subcounty, Migori County Kenya. International Journal of Secondary Education. Vol. 4, No. 5, 2016, pp. 44-57.doi: 10.11648/j.ijsedu.20160405.11

Received: November 14, 2016; Accepted: December 1, 2016; Published: January 9, 2017

\begin{abstract}
Secondary school education provides a foundation for acquisition of further knowledge and skills in tertiary institutions of learning. It is a bed-rock where future productive human capital is nurtured to serve the dynamic needs of a nation's labour market and the economy in general. Education is used to achieve more rapid economic, social, political, technological, scientific and cultural development in a country. In Kenyan education system, mathematics is a compulsory and an examinable subject offered at all levels of learning except for tertiary institutions where it is selective, yet requisite in some courses of study. There is much emphasis on mathematics performance examined nationally by the Kenya National Examinations Council (KNEC) hence necessitating the current study. As a matter of fact, students' performance in mathematics has attracted attention from various stakeholders and further raised interest in teachers' qualification in delivering the subject matter. This study ought to establish the influence of teacher competence on mathematics performance in KCSE examinations among public secondary schools in Nyatike Sub-county, Kenya. Teacher competence was conceptualized in terms of teacher educational qualification, teacher training and teacher experience and mathematics performance as the dependent variable. The study was based on three models namely; economical approach, stakeholder theory of management and humanistic-progressive model. The study used a descriptive research design with a survey method and targeted 50 public secondary schools. The researcher used structured questionnaires to collect data from the sampled respondents. The collected questionnaires were then analyzed using SPSS version 20. Both linear regression analysis and Pearson correlation analysis were used and the results presented in tables. The study findings revealed positive correlations between; teacher educational qualifications with mathematics performance, teacher training with mathematics performance, and teacher experience with mathematics performance. However, it was also noted thatsome teachers holding diplomas from reputable colleges such as Kenya Science University College perform better than those with undergraduate degrees from universities.
\end{abstract}

Keywords: Teacher Competence, Mathematics Performance, Qualification, Teacher Training and Teacher Experience

\section{Introduction}

\subsection{Background to the Study}

Education at secondary school level often provides a foundation for acquisition of further knowledge and skills in tertiary institutions of learning. It is a bed-rock where future productive human capital is nurtured to serve the dynamic needs of a nation's labour market and the economy in general. Education is regarded as an instrument that can be used to achieve more rapid economic, social, political, technological, scientific and cultural development in a country. According to [22] secondary education is a very important instrument for national development that fosters the worth and development of the individual for further education and development as well as the general development of the 
society. In Kenyan education system, mathematics is a compulsory and an examinable subject offered at all levels of learning except for tertiary institutions where it is selective, yet requisite in some courses at different years of study.

Over the recent years, students' performance in mathematics has attracted attention from various stakeholders and further raised interest in teachers' competence in delivering the subject matter. Some scholars opine that student performance in mathematics is a function of student effort, attitudes, interest in the subject and intellectual capabilities as well as competence of the teacher. As regards teachers' roles in student achievement in mathematics, there are various competency standards required in the teaching profession. These standards relate to teacher competence requirements such as the level of educational qualification, training \& professional development and work-related experience [49]. Competent teachers who meet the profession's requirements are perceived to be "good" teachers who bring about learning and exhibit desirable traits by upholding the standards and norms of the profession [52]. This study relates teacher competence with student performance in mathematics examined nationally by the Kenya National Examinations Council (KNEC). Competence, in this case, entails teacher qualification, experience and professional training.

Teacher qualification entails the level of attainment or achievement in professional training that determines the quality of services offered based on competence of individual teachers. According to [1] teacher qualification refers to academic or professional achievement that enables an individual to become a competent teacher.A qualified teacher is one who holds a teaching certificate earned from a reputable and accredited institution and is thus licensed to offer services in his/her area of specialization [32]. According to [1] teacher qualification can be described in terms of the level of certification earned by the teachers including Postgraduate Diploma in Education (PGDE), Professional Diploma in Education (PDE), Bachelor of Education (B.Ed) among others. These qualifications determine the level of competence for each subject teacher. [49]defines competence as the ability of a professional to apply knowledge, skills and experiences in performing activities within a given occupation in order to produce a required outcome.From the teaching point of view, teacher competence involves an individual teacher's ability to function as expected in employment and do a particular job or perform a set of tasks under various conditions including the ability to cope with contingencies. According to [42], teacher competence is highly associated with professional performance and can be defined from both cognitive and operational perspectives. From the theoretical point of view, teacher competence refers to a cognitive structure that facilitates specified behaviours. From the operational perspective, it entails a myriad of higher-order knowledge, skills, attitudes, strategic thinking, metacognition and behaviours that represent the teacher's ability to deal with complex situations that cannot be predicted with precision[42].

Competence has mental component involving thought and a behavioural component involving competent professional performance. To influence the desired student performance in mathematics, teacher competence goes beyond mere possession of the requisite knowledge, skills and attitudes [22]. This is because the success of any pedagogical process also relies on other factors such as the mode of delivery of content, teacher preparedness, learner engagement in the learning process, the learning environment among others. In this study, teacher competence is looked at in terms of three key factors; educational qualification, training and experience in the teaching profession. According to [42] competence is developed through teacher education, work experience and on-the-job training based on an expossure to a variety of activities that test an individual's ability to cope with different situations. Teaching experience gained also improves the teachers' ability to cope with unusual circumstances while education provides the teacher with solid understanding of the subject matter. Education and work-related experience also enhance the teacher's understanding of the principles and concepts underlying efficient and effective delivery of mathematical content.

Mathematics is one of the subjects taught in Kenyan Secondary schools and is examined that by the Kenya National Examinations Council (KNEC) in Kenya Certificate of Secondary Education (KCSE) as a compulsory subject for all candidates. Performance in mathematics can be described in terms of results attained from outcomes attained. Schools' overall performance in mathematics is a function of both teacher and student input. It can be described based on the grades attained by the individual students and the overall school performance in the subject.In many public schools, achievement in the subject remains dismal despite its role in career choice and day-to-day application of mathematics in decision-making [3]. Based on its relation to other subjects, mathematics is also necessary for course selection at tertiary institutions of learning. [3] observe that while performance in mathematics lags behind relative to other subjects, gender disparity persists in relation to student performance in mathematics. Male students perform better in mathematics compared to their female counterparts.

A study done by [37] indicates that mathematics performance depends on the success of the teaching process which is a multidimensional construct measured through evaluation of the overall achievement by students. It also depends on motivation of the students as well as the evaluation of the teacher's role. In addition, mathematics performance is varies from school to school, set-up of the learning environment, availability of resources and infrastructure that support learning and the type of schoolwhether private, public, day-school or boarding school. [37]opine that schools in urban areas in Kenya perform better that rural schools since learning materials and examinations are prepared and administered to all students without considering their learning environments. This affects the overall performance of rural schools. Other factors 
contributing to poor performance in mathematics include mismatch of the syllabus, negative attitudes towards mathematics by some teachers and students and difficulties inherent in the subject itself [36]. According to [36] other factors inhibiting mathematics performance in Kenya Certificate of Secondary Education (KCSE) examinations include lack of proper lesson planning, poor teaching methodology, poor pace of work coverage, poor topic sequencing and use of unsuitable learning resources.

$\mathrm{KCSE}$ is a merit-based certificate provided by the Kenya National Examinations Council (KNEC) to secondary school students upon successful completion of secondary education. Prior to receiving the certificate, a student has to examinations council requirements by sitting for the required examination papers examined by KNEC. The examination papers are administered by the KNEC annually to students who have completed secondary education. The subjects examined in KCSE are broadly classified in to five major groups. According to this classification, the first group consists of compulsory subjects including English, Mathematics and Kiswahili. Whereas group two comprises of sciences, group three consists of humanities while group four is made up of practical subjects and group five consists of applied subjects.

According to KNEC's regulations, a student is obliged to take all the compulsory subjects, at least two sciences, one of the humanities and at least one practical or applied subject. The KCSE examinations are administered over a period of one month, once every year between October and November and the results subsequently released in February the following year [23]. The examinations are taken under very strict supervision to ensure cases of cheating and other exam malpractices are minimized. However, in the event that the examinations council detects any exam malpractice or cheating, the results of the students involved are cancelled and stern action taken against all persons involved. Over the years, the number of KCSE candidates has been increasing constantly. KNEC statistics indicate that the number of all candidates who sat for KCSE examinations countrywide were 522,820, representing an $8.11 \%$ increase from the previous year. In Migoricounty, the number of KCSE candidates in 2015 was 12,367. Mathematics being a compulsory subject, all the candidates sat for the mathematics examinations [23]. However, the KCSE examination results statistics indicate that the overall performance in mathematics was relatively low compared to other subjects.

\subsection{Statement of the Problem}

The education system in Kenya has a comprehensive curriculum that makes mathematics a core subject meaning that it is a compulsory subject for all learners up to secondary school level of education. As such, all students seeking to acquire KCSE certificates upon completion of secondary education have to study mathematics and sit for it in the KCSE examinations. This is because mathematics relates with other subjects and provides a solid foundation for other fields such as commerce, medicine, engineering, agriculture among others. In this case, mathematics is at the core of learning at all levels of education. However, mathematics performance in KCSE has been poor in Nyatike sub County and nationally in general despite all the initiatives undertaken by the stakeholders to improve student achievement in the subject. For example, the results for KCSE 2015 examinations indicate that the overall mathematics performance was below 50\% nationally. Mathematics Alternative A recorded 26.88\% while Mathematics alternative B had a national mean score of $28.29 \%$. Even in Nyatike sub-county, the statistics indicate that the performance in mathematics wasn't any different [23]. This has attracted the attention of many education stakeholders including parents, teachers, KNEC, the government and other external stakeholders funding education projects in Kenya. Studies have been done to explain the factors underlying the reported poor performance in mathematics and various correlates established. This study sought to assess the influence of teacher competence on mathematics performance among public secondary schools in KCSE examinations, in Nyatike Sub County, Migori County Kenya. The contemporary practice in the service sector appraisals is such that human resource professionals relate the attainment of desired institutional achievements to employee competence beside other attributes. It is on this basis that the researcher finds it fit to relate teacher competence with student performance and hence the need to conduct the present study.

\subsection{Purpose of the Study}

The purpose of the study was to assess the influence on teacher competence on mathematics performance in KCSE examinations among public secondary schools in Nyatike Sub County, Migori Kenya. The study sought to establish the influence of teacher qualification, training and work-related experience on mathematics performance of public secondary schools in Nyatike sub-county Migori County Kenya.

\subsection{Objectives of the Study}

i. To establish the teacher educational qualification on mathematics performance in KCSE examinations among public secondary schools

ii. To find out the teacher training on mathematics performance in KCSE examinations among public secondary schools

iii. To investigate the teacher experience on mathematics performance in KCSE examinations among public secondary schools

\subsection{Research Questions}

i. In what way does teacher educational qualification influence mathematics performance in KCSE examinations among public secondary schools?

ii. How does teacher training have influence on mathematics performance in KCSE examinations 
among public secondary schools

iii. How does teacher experience influence mathematics performance in KCSE examinations among public secondary schools

\subsection{Justification of the Study}

This study was expected to be important in establishing the role of teacher competence in improving mathematics performance in KCSE examinations in public secondary schools. The findings of the study established the rationale for considering teacher qualification, training and experience in the subject matter at employment. The study also enables education administrators and managers understand the necessity of ensuring teachers take further training and professional development as a milestone to improve mathematics performance in KCSE examinations. The study findings will also be useful to the Teachers Service Commission (TSC) as an employer and the Ministry of Education in setting standards and monitoring performance of teachers and schools. The study also enables education financiers to realize the need to invest more in developing teacher competencies as a means to improving performance in mathematics.

\section{Literature Review}

\subsection{Theoretical Review}

In this section, the economic model, stakeholder theory and the humanistic progressivetheory are reviewed and discussed in context of the current study in order to apply them in conducting and understanding the interrelation between teacher competence and mathematics performance.

\subsubsection{Economical Approach}

The economical approachis aimed at quantitatively measurable inputs (goals) and outcomes of education. This approach is operationalized through the concepts of competence including academic qualification, professional training and experience of teachers in the educational institutions. Teacher competence denotes whether certain teacher potentials and individual capabilities have positive influence on educational achievements in mathematics. Efficiency relates to the relation between the monetary expressed input and the appropriate outcome of the educational system. The more efficient system is the one in which the results are higher than the funds invested [8]. However, the shortcoming of the economic approach is that not all elements of education are quantitatively measurable, which narrows the aspect of evaluation only to the cognitive educational achievements and the product itself.

\subsubsection{Stakeholder Theory of Management}

The stakeholder theory was first developed by Freeman in 1980. The theory explains a stakeholder as people with interest in an organization. In this regard, the stakeholder can directly or indirectly be affected by the actions, objectives, policies and strategies of the organization and vice versa. A stakeholder can be an employee, supplier, shareholders, customer or a member of the board of management. The stakeholder theory states that organizations should attach great value to the stakeholder because without the stakeholder's support the organization would collapse or cease to be sustainable [13]. In delivering its services, the school relies on its employees and strategic partners who offer the services to the customers. It is, therefore, important for the key education stakeholders to keep the interest of all concerned parties aligned and gear them in the same direction. The theory has three aspects that mutually support each other i.e. the instrumental approach, normative approach and the descriptive approach. The instrumental approach is for identifying the connection between achievement of institutional goals and the group of stakeholder management using empirical data.The normative approach is considered to be the most important aspect because it identifies the moral and physiological guidelines for strategy, operations and management of an organization.In the descriptive approach, it explains the characteristics of individuals in organizations and also the inherent behaviors' [13]. The theory's core function is to establish the balance of the interests for the different stakeholders and so for this to be accomplished the stakeholders must be identified.This theory applies to this study as it enhances the consideration of the competencies of the teachers as the key stakeholders from whom the society expects better educational performance.

\subsection{Empirical Review}

This part reviews empirical studies that have been conducted by different scholars on areas touching teacher qualification, teacher training and teacher experience in relation to mathematics performance in KCSE examinations.

\subsubsection{Teacher Educational Qualification}

The Teachers Service Commission (TSC) is a semiautonomous government agency that recruits and employs teachers both in primary and secondary levels of education. As statutory requirement, the TSC enforces legislation relating to recruitment and employment of teachers in Kenya. As such, TSC together with other stakeholders in education set the minimum educational qualification requirements that have to be satisfied by any individual prior to being offered a job as a teacher. According to the TSC staff recruitment policy guidelines, any person seeking an employment opportunity as a secondary school teacher in Kenya must have earned at least a Diploma in Education from a reputable university. However, teachers in various schools are employed with various education qualifications including those holding undergraduate degrees, masters and even higher qualifications [18]. In this case, teacher educational qualification is taken to be commensurate with the teacher's understanding and mastery of mathematical knowledge [20]. This paper seeks to establish the influence of teacher qualification on mathematics performance in public secondary schools in Nyatike Sub-county. The study is guided by the following reviewed literature. 
The environment where learning takes place influences the quality of learning and hence the actual outcomes of learning. The learning environment comprises the school setting, resources, learning content, the learner and the teacher. [18], like many other researchers, have concluded that the school effect on achievement in mathematics derives mainly from variations in teacher quality. On the basis of longitudinal data from more than one-half million Texas students in grades 3 to 6 , they concluded that school quality is an important determinant of academic performance and an important tool for raising the achievement of low-income students. Studies also indicate important gains in teaching ability over the first few years of teaching, but that these effects decline after the first several years. A study done by [33] on the impact of teacher qualification in Publicand independent schools in Sweden indicates that master's degree was not found to be associated with improved teacher competence in delivering mathematical content in secondary schools. The estimates in this study suggested that differences in teacher quality explained at least 7.5 percent of the variation in measured achievement. However, measured factors captured just a small proportion of the differences among teachers. From these results the authors drew the conclusion that teacher education is a small component of variation in school quality. Other studies indicate that having higher order academic achievements such as a master's degree had no influence on student performance [29] \& [10].

According to [10], subject-matter knowledge has often been found to be an important factor in teacher effectiveness. However, its relationship to teaching performance is curvilinear: it exerts a positive effect up to a threshold level and then tapers off in influence. Measures of pedagogical knowledge including knowledge of learning, teaching methods and curriculum have more often been found to influence teaching performance, and frequently these factors exert even stronger effects than subject matter knowledge. However, study done by [18] indicate that teaching experience and highest degree earned alone it is not possible to link the length and content of teacher education to students' achievement. [19] and [20] argue that government policies targeting school resources, including raising qualifications of teachers do not effectively improve quality examination outcomes. Added requirements for teacher certification, for example, show no strong relation to teacher quality and student achievement. [11] on the other hand, stressed the difficulty of generalizations about teachers' qualifications based on certification status only, since both regular certification and short-term certification operate under widely different standards in different counties.

[14] noted in a longitudinal study that well-qualified teachers had a significant influence on high school students' achievement in mathematics and science. In this study teacher qualification was measured by education, experience and teaching methods. [15]compared well-educated teachers with less educated teachers. The results showed achievement gains for students with well-educated teachers. They also showed that achievement was related to teachers' knowledge of the subjects taught. In a study involving 7000 students [34] found that the quality of the teaching force has a comparable impact on students' test scores as socioeconomic status. [9]investigated students' test results in reading and mathematics. In the study 44 states with 65000 teachers were included. The data comprised several variables indicating teacher competence, such as certification and experience. A number of other variables were included in the study such as education policy, demographics, student characteristics and school characteristics. Controlling for student background, teacher certificate and subject matter knowledge were shown to correlate with students' test results and to have great explanatory power. In a review, [50] examined the evidence on teacher characteristics and student test scores in a U.S. sample, controlling for students' prior achievement and socioeconomic status. [49]could not draw any conclusions about the importance of teacher degrees and coursework for elementary students since too few studies were available. Results showed, however, that high school students' mathematical achievement improved when their teachers had standard certification.

Individuals who have had no strong teacher education intervention often maintain a single cognitive and cultural perspective that makes it difficult to understand experiences, perspectives and knowledge bases of students who are different from themselves. Teachers from extended programs are more satisfied with their preparation. Their colleagues and principals view them as better prepared, they are as effective with students as are more experienced teachers and they are more likely to stay in their profession. These teachers come to understand teaching as an inherently nonroutine endeavour where they develop pedagogies that can reach different learners. In their meta-analysis, [50] opine that they would like to see studies that explicitly distinguish between degrees in subjects and degrees in the teaching of particular subjects, as well as studies that distinguish degrees in the teaching of particular subjects from general degrees in teaching or education.

\subsubsection{Teacher Training}

The teaching profession comprises one of the most important human resources in every country. This is so because the efficient human capital development depends partly on the quality and effectiveness of the teachers [5] and [39]. The quality and effectiveness of the teacher is among others a function of the talent and the professional training. [30] and [34] observe that trained teachers yield better results in mathematics compared to the untrained teachers. The trained teachers confidently exhibit better understanding of the knowledge, principles and concepts in delivery of mathematical content. According to [30] training of teachers is one of the most important aspects of curriculum development and implementation in any education system. In this study, the training of teachers is considered from two perspectives i.e. a pre-service training and in-service training. According to [24] the Assistance for Development of Education in Africa (ADEA) states that the adequate pre- 
service skills training which is somewhat sufficient for providing orientation to the teacher into the profession is generally formed in the classroom. Other than the basic training teachers receive in colleges and universities, professional training and development is also very necessary in the teaching profession as a means of enhancing teacher competence and student performance [6].

[24] explain that mathematics education development especially at the secondary level is a prerequisite for industrial and technological development. In the past, great efforts have gone into ensuring qualified teachers and provision of equipment and materials, but in most cases science and mathematics teachers remain inadequate in most African countries. Even where they are adequate, quality of students' achievement in mathematics is not always high [24]. It is with this background that the attention is now drawn to what teacher competences, classroom practices, utilization of the available equipments and materials, and approaches and methodologies are employed in mathematical content delivery. This is a critical component to the answer to mathematics and science education problem [25]. This is the basis for the Strengthening Mathematics and Science in Secondary Education (SMASSE) project with an In-Service Education Training (INSET)[48]. Consequently, [2] recommends a strong ongoing in-service professional development program for secondary teachers that will support them throughout their teaching careers. This seems to fit into the Kenya government collaboration with Japan International Cooperation Agency (JICA) in coming up with the SMASSE project [26].

Strengthening Mathematics and Science in Secondary Education

SMASSE is an educational program whose aim is to help improve the performance of Science and Mathematics in Kenyan secondary schools. It is a joined venture between the Kenya Government through Ministry of Education, and Government of Japan through JICA initially on pilot basis. SMASSE came into being when the consistently poor performance in Mathematics and Science became a matter of serious concern. Broad curricula, lack of facilities and inadequate staffing were always cited as the major causes of the problem. Although dismal performance in these subjects had almost been accepted as the norm in some schools, the education stakeholders felt the need for an intervention, hence the Strengthening of Mathematics and Science in Secondary schools [35].The SMASSE program was implemented over a 10 year period (from 1998 to 2008), with marked strides. In the first phase of the project (June $1998-$ June 2003), activities were initiated on a pilot basis in nine (9) Districts (Butere, Gucha, Kajiado, Kakamega, Kisii, Lugari, Makueni, Maragua and Murang'a). Six additional districts (Baringo, Garissa, Kiambu, Kilifi, Meru South and TaitaTaveta), were brought on board in 2001, bringing the number of districts in the pilot phase to 15 . The second phase was implemented from July 2003 - June 2008, on national scale. By the end of the project, a total of 108 district centres for INSET had been established in public secondary schools throughout the country.

Some of the aims of SMASSE training program include upgrading teacher's content in their subject areas and provide forum for mathematics/science teachers to meet and exchange ideas and experiences through peer teaching and lesson observation [21]. It also sought to develop good work plan as a way of ensuring well utilization of available resources in terms of money and time and identifying ways of creating and sustaining interest. In addition, the program aimed at bringing about attitude change in the mathematics among education stake holders, policy makers, administrators, teachers, learners and parents. Another aim of SMASSE was to quip teachers with skills for proper use of innovations as a problem solving in this era of $21^{\text {st }}$ century which is characterized by technological changes [21]. Importantly, the INSET training under the SMASSE program is credited with improved performance in mathematics among schools where teachers take part in the training.

\subsubsection{Teacher Experience}

One common indicator of teacher quality is the teaching experience expressed in terms of the number of years served as a subject teacher as well as the number of years an individual teacher interacts and shares ideas and insights with peers in the working environment. [43] observes that experience gained by teachers over time enhances their knowledge, skills, work effectiveness and productivity in delivering the desired outcomes. Teacher effectiveness is very high especially during the first few years of service with the TSC. However, as time goes, the impact of experience becomes strong during the first few years of teaching and afterwards marginal returns diminish gradually[31]. In fact, studies indicate that early career experience enhances teacher effectiveness and productivity during the first few years of service after which the teachers' performance diminishes [43]. An important aspect of teacher experience that influences teacher and student outcomes in mathematics is benchmarking in the subject matter. According to [16], benchmarking in mathematics is an interactive system of achieving improved academic performance for students. Benchmarking system is used to motivate students by way of mastery learning in a new environment to improve student performancein mathematics. According to [19] benchmarking is done once a problem relating to poor performance is identified and a need to improve the student performance in the subject realized based on relevant policies set to fill the identified performance gaps. As a result of benchmarking, teachers also benefit by being able to develop professionally to an extent that they learn how to deliver the mathematical content effectively and efficiently [16].

According to [50], the findings regarding experience are difficult to interpret for several reasons. This is because experience captures the effect of whether teachers were hired during a shortage or a surplus. In addition, interpretation of experience can be impeded by the fact that experience measures capture differences in teacher motivation resulting from time constraints on parents during years when their own 
children require more attention. Finally, if there are differences in effectiveness between those who leave the profession and those who stay, experience measures would capture those as well. Such differences may be dynamic and changing with labour markets and cultural trends.Several studies have found a positive relationship between teacher experience and student achievement [31] \& [25]. This relationship is not simple and linear however. According to [9], teachers with less than three years' experience are less efficient than are colleagues with more experience. After five years the additional contribution weakens. [4]noted that inexperienced teachers from lengthy teacher education programs can be as efficient as experienced teachers. Teachers' age may also be of importance for effectiveness but this variable is of course highly correlated with experience. Other studies of the effects of teacher experience on student performance have found a relationship between teachers' effectiveness and their years of experience [31] \& [25]. While many studies have established that inexperienced teachers (those with less than three years of experience) are typically less effective than more senior teachers, the benefits of experience appear to level off after about five years, especially in non-collegial work settings [43]. A possible cause of this curvilinear trend in experience effects is that older teachers do not always continue to grow and learn and may grow tired in their jobs.

Furthermore, the benefits of experience may interact with educational opportunities. Veteran teachers in settings that emphasize continual learning and collaboration continue to improve their performance [43]. Similarly, very wellprepared beginning teachers can be highly effective. For example, some recent studies of 5-year teacher education programs--programs that include a bachelor's degree in the discipline and master's in education as well as a year-long student teaching placement--have found graduates to be more confident than graduates of 4-year programs and as effective as more senior teachers [4] \& [12]. It is also possible that uneven effects of experience in cross-sectional studies can be the result of cohort effects (for example, cohorts of teachers hired in times of shortage may be less well-qualified than those hired when schools can be more selective) or of attrition effects (for example, disproportionate early attrition of more able teachers may leave a less capable senior force on average) [30].

\subsubsection{Mathematics Performance}

Performance in mathematics is reflected by the results attained from KCSE examinations and other internal examinations administered by the subject teachers. Schools' overall performance in mathematics is a function of both teacher and student input. It can be described based on the grades attained by the individual students and the overall school performance in the subject. In many public schools, achievement in the subject remains dismal despite its role in career choice and day-to-day application of mathematics in decision-making [3]. Based on its relation to other subjects, mathematics is also for course selection at tertiary institutions of learning. In addition, [3] observed that while performance in mathematics lags behind relative to other subjects, gender disparity persists in relation to student performance in mathematics. Male students perform better in mathematics compared to female students.

A study done by [37] indicates that mathematics performance depends on the success of the teaching process which is a multidimensional construct measured through evaluation of the overall achievement by students. It also depends on motivation of the students as well as the evaluation of the teacher's role. In addition, mathematics performance varies from school to school, set-up of the learning environment, availability of resources and infrastructure that support learning and the type of schoolwhether private, public, day-school or boarding school. In line with the aim of this study, [21] conducted a similar study relating teacher competence with student performance in mathematics among senior secondary schools in Kaduna Sate, Nigeria. The study results indicated that teachers having high levels of competence in mathematics provide much detail in their lessons, utilize their expertise to link a particular topic other topics and further break down abstract mathematical knowledge into simpler and more polished forms. They also ask students many relevant questions to evaluate the extent of success of the learning process and stray from the text books when delivering mathematical content [26] and [45]. Competent teachers achieve the goals they set for themselves as well as those set for them by other stakeholders and make up for the deficiencies of the curriculum.

[37] observe that schools in urban areas in Kenya perform better that rural schools since learning materials and examinations are prepared and administered to all students without considering their learning environments. This affects the overall performance of rural schools. Other factors contributing to poor performance in mathematics include mismatch of the syllabus, negative attitudes towards mathematics by some teachers and students and difficulties inherent in the subject itself [36]. Other factors inhibiting performance in mathematics include lack of proper lesson planning, poor teaching methodology, poor pace of work coverage, poor topic sequencing and use of unsuitable learning resources.

\subsection{Research Gaps}

Performance in mathematics unlike other subjects offered in secondary schools in Kenya has been lagging behind as reported in KCSE examination results. This has attracted much attention of the education stakeholders and as such inquiries have been done to unearth the potential causes and correlates of the dismal performance in the subject. Various scholars have conducted studies on student performance in mathematics at secondary school levels. [39] did a study in Nigeria to assess the effects of teacher effectiveness on student achievement in mathematics and revealed that the performance of students in mathematics depends on teacher qualification and experience. The study also indicated that it is necessary for teachers to have all the requisite teaching 
resources to enhance the quality of their output. However, the study never took into account the possible influence of teacher experience in marking national examinations on student performance [41]. The study also did not lay emphasis on quality of classroom instructional in the subject matter.

A study done by [42] relating teachers teaching experience and academic performance in Mathematics and English language in public secondary schools revealed a positive correlation between teaching experience and student performance. According to [25], in their study of the influence of teacher characteristics on students' academic performance among secondary schools, they establish that student performance is not influenced by the level of educational attainment of the respective subject teachers. In addition, the study reveals no significant relationship between teacher qualification and student academic achievement. Considering the emphasis on mathematics performance among individual students, the performance in the subject still remains below average nationally. Also, since the introduction of mathematics options A and B respectively in Kenyan education system, none of the above studies ever emphasized on the relationship between teacher qualification and performance in each option.

\subsection{Summary of Reviewed Literature}

This study seeks to assess the influence of teacher qualification on mathematics performance in KCSE examinations. The study is based on three theories namely, economical theory, stakeholder theory and humanistic progressive approach. In this chapter, an elaborate review of the existing literature on teacher qualification and mathematics performance among public secondary schools is done. As regards teacher qualification, variables such as teacher educational qualification, work experience (teaching experience and marking of national examinations) and teacher training (pre-service training and in-service training) are detailed and further conceptualized in relation to mathematics performance. In fact, the performance in mathematics in KCSE examinations was looked at in terms of subject mean score for the school, quality grades attained and the overall mean score for each school.

\section{Methodology}

The purpose of this chapter is to provide a guideline as to how the objectives of the study will be achieved. It covers the research design, target population, sampling techniques, sample size determination, data collection instruments, pilottesting data collection procedure and data analysis.

\subsection{Research Design}

According to [26] a research design is a guideline as to how the objectives of the study would be fulfilled. The study applied a descriptive research design with a census strategy. The focus of the study was to assess influence of teacher competence on mathematics performance hence most of the data will be both qualitative and quantitative and hence the need to use descriptive research design. Descriptive research design was appropriate because the researcher could generalize the findings to the whole population.

\subsection{Target Population}

Population refers to all individuals, items or objects from which you want to draw a conclusion in a specific study. [49] defines a population as a group of all possible elements that could be observed or measured theoretically. The target population of this study comprised of teachers, heads of mathematics departments and principals of all the 50 public secondary schools in Nyatike sub county, Migori County Kenya. The researcher intended to collect data from the entire target population of the study.

\subsection{Sample Size and Sampling Technique}

A sample is described as a subset of the population or a representative of the whole population [49]. Sampling on the other hand refers to the process of selecting a subset of the population.

\subsubsection{Sampling Frame}

Sampling frame is the source material or rather list of the population from which the sample was drawn. According to [44] sampling frame refers to that which is used to identify the objects, individuals or elements in each sampling unit. The primary purpose of a sampling frame was to provide a way for selecting members of the target population. The sampling frame consisted of principals and heads of departments from public secondary schools in Nyatike subcounty.

\subsubsection{Sample Size Determination}

The sample size was determined by the use of Narssiuma's formula as been shown below.

$$
\mathrm{n}=\frac{N \times C^{2}}{C^{2}+(N-1) \breve{\mathrm{e}}^{2}}
$$

$(\mathrm{n}=$ sample size, $\mathrm{N}=$ Population size, $\breve{\mathrm{e}}=$ tolerable error (5\%), $\mathrm{C}=$ coefficient of Variation $(0.5)$ )

$$
\begin{gathered}
\mathrm{n}=\frac{50 \times 0.5^{2}}{0.5^{2}+(50-1) 0.05^{2}} \\
\mathrm{n}=34
\end{gathered}
$$

\subsubsection{Sampling Procedure}

The sample size was determined using Nassiuma's formula and the sampled respondents were derived using systematic sampling. The main consideration for determining the sample size was to ensure that the study represents the entire population while at the same time keeping the research manageable [51]. All schools have principals and subject teachers despite their size and are therefore eligible to be sampled. 


\subsection{Data Collection Instrument}

The researcher used structured questionnaires to collect the required data from the sampled respondents. Closed ended questions were used in the questionnaire. The structured questionnaires were administered to the respondents through a drop and pick method. The researcher also supplemented the questionnaires with interviews to obtain more detailed and first-hand information from the respondents.

\subsection{Pilot Test}

A Pilot test is a mini-study done in preparation for the main study. It is a small study conducted in order to design a further confirmatory study. The pilot study is important in detecting possible errors in the measurement procedures, identification of unclear questions in the questionnaire and determining the validity and reliability of the data that was to be collected. For this study 5 schools were selected randomly for the pilot test and questionnaires sent to them. SPSS version 20 was used to analyze the pilot data to determine the validity and reliability of the data research questionnaire [27].

\subsubsection{Validity of Research Instrument}

According to [17] validity is concerned with whether the research measures what it is intended to measure or rather how true the research findings are. Unsystematic threats to reliability include unforeseen happening before or during data collection, participants' refusal to cooperate and change of behavior of the participants. To guarantee validity, the researcher conducted face and content validity test on the measuring instrument and had the test reviewed by the faculty and obtained feedback. This ensured that the objectives were clearly defined and operationalized expected results.

\subsubsection{Reliability of Research Instrument}

Reliability refers to the degree at which a researcher's data is free from error and hence yields consistent findings [46]. The data should be consistent over time as well as be an accurate representation of the population under study. However, the researcher conducted a pilot study to test the extent to which the measuring instrument can be relied upon. To ensure reliability of the measuring instrument, careful wording, format and content was used. In this study, the researcher did a pilot study in five schools and Cronbach's alpha $(\alpha)$ with a reliability threshold $(\alpha \geq 0.7)$ was deemed fit and acceptable to test the internal consistency of the measuring instrument.

\subsection{Data Collection Procedure}

The researcher approached the management of each of the schools in the population and sought permission and guidance on the appropriate approach to data collection. The researcher then distributed the data collection instruments tothe respondents to fill in the questionnaires. In other cases, the researcher conducted interviews to obtain first-hand information from the respondents [51]. The researcher also utilized scholarly journals, and use of internet in collection of data.

\subsection{Data Analysis and Presentation}

Data collected was analyzed using inferential statistics. The analysis used a combination of correlation and regression techniques to determine an overall picture of the variables in the population. As soon as the collection of the data was finalized and compiled, the data was classified, coded and analyzed using the Statistical Package for Social Sciences (SPSS). Also, inferential statistics were used and in particular, the researcher conducted both Pearson correlation analysis and a regression analysis to show the effect of the independent variables on the dependent varriable. The following regression model was used to determine the influence of the independent variables on the dependent variable

$$
\mathrm{Y}=\mathrm{a}+\beta_{1} \mathrm{C}_{1}+\beta_{2} \mathrm{C}_{2}+\beta_{3} \mathrm{C}_{3}+\breve{\mathrm{e}}
$$

Where:

$\mathrm{Y}=$ Mathematics Performance

$\mathrm{a}=$ Constant

$\beta_{\mathrm{i}}=$ Coefficients to be estimated

$\mathrm{C}_{1}=$ Teacher Educational Qualification

$\mathrm{C}_{2}=$ Teacher Training

$\mathrm{C}_{3}=$ Teacher experience

$\mathrm{e}=$ Error term

\subsection{Research Ethics Considerations}

In conducting the present study, the researcher considered the ethical issues in research by appropriately acknowledging all the sources of information used and further making correct citations within text and in the bibliography sections. The researcher ensured originality of the study content by avoiding plagiarism and abiding by the guidelines that protect respondent confidentiality and privacy. [26] asserts that the researcher has to ensure the study does not harm or affect the study participants. Importantly, the researcher sought permission to conduct the study from the sampled schools by presenting a letter of request to conduct a study to each of the sampled schools to be allowed to conduct the study.

\section{Research Findings}

\subsection{Response Rate}

[47] defines response rate as the number of units in the net sample expressed as a percentage of the units in the gross sample. In this study, all the 34 questionnaires that were issued to the respondents were filled, returned and cleaned and only 31 questionnaires were used in the analysis. Therefore, all the used questionnaires represent a response rate of $91.2 \%$. 


\subsection{Reliability Analysis Results}

The researcher determined the extent to which the research instrument could be relied upon prior to conducting the actual study and the pilot results obtained were as shown in table 1

Table 1. Reliability Analysis Results

\begin{tabular}{lll}
\hline Construct & Cronbach's Alpha & N of Items \\
\hline Teacher Educational Qualification & .750 & 5 \\
Teacher Training & .790 & 5 \\
Teacher Experience & .762 & 5 \\
\hline
\end{tabular}

\subsubsection{Mathematics Teachers by Gender}

Table 2 shows the distribution of the mathematics teachers depending on their gender. According to the findings, $74.2 \%$ of the mathematics teachers were male while only $25.8 \%$ were female teachers (Table 2). The reason attributed to this may be due to the claim that ladies generally perform better in languages than they do in mathematics and sciences.

Table 2. Distribution of Mathematics Teachers by Gender.

\begin{tabular}{cll}
\hline Gender & Frequency & Percent \\
\hline Male & 23 & 74.2 \\
Female & 8 & 25.8 \\
Total & 31 & 100.0 \\
\hline
\end{tabular}

\subsubsection{Teachers' Educational Qualification}

Table 3 shows the distribution of the mathematics teachers according to their educational qualifications.

Table 3. Distribution of teachers by Educational Qualification.

\begin{tabular}{cll}
\hline Educational Qualification & Frequency & Percent \\
\hline Diploma & 4 & 12.9 \\
Undergraduate Degree & 23 & 74.2 \\
Masters and above & 4 & 12.9 \\
Total & 31 & 100.0 \\
\hline
\end{tabular}

From Table 3, the study established that $12.9 \%$ of the respondents had attained diplomas, $74.2 \%$ have undergraduate degrees, and another $12.9 \%$ have masters and above qualifications. This implies that quite a majority of the teachers have at least an undergraduate degree qualification with specialization in mathematics and that they pursue higher order academic qualifications.

\subsubsection{Teachers Experience}

Table 4 shows the distribution of the mathematics teachers according to the number of years they have been teaching KCSE candidates.

Table 4. Distribution of Respondents by experience in teaching KCSE Candidates.

\begin{tabular}{lll}
\hline Experience & Frequency & Percent \\
\hline 0-5 years & 10 & 32.3 \\
5-10 years & 6 & 19.4 \\
10-15 years & 7 & 22.6 \\
over 15 years & 8 & 25.8 \\
Total & 31 & 100.0 \\
\hline
\end{tabular}

It is evident from Table 4 that $32.3 \%$ of the teachers had taught KCSE candidates for five years and below, 19.4\% have taught KCSE candidates for a period ranging between $5-10$ years while $22.6 \%$ have $10-15$ years experience teaching the KCSE candidates and $25.8 \%$ of the mathematics teachers have taught KCSE candidates for over 15 years. This implies that over the last five years, the Teachers' Service commission has been recruiting more human capital to deliver the subject matter to the learners. This can possibly be attributed to the high enrollment rates in secondary schools that call for recruitment of many more teachers to deliver then mathematical content to the learner. Similar to the study findings of [16] it is likely from the findings of the present study that over the preceding years, TSC had been acquiring and developing human resources in nearly equal proportions every year.

\subsection{Inferential Analysis}

This particular study focused on how teacher competence influences mathematics performance in KCSE examinations by public secondary schools in Nyatike Sub-county. The indicators of teacher competence analyzed in this study included the teacher educational qualification, teacher training and teacher experience. Correlating each of these competence indicators with the school KCSE performance in mathematics enabled the researcher to determine the inherent relationships. Also, a multiple regression analysis was done to assess the extent to which the teacher competence relates with mathematics performance in KCSE.

\subsubsection{Teacher Educational Qualification and Mathematics Performance}

This section outlines the results of correlation analysis between teacher educational qualification and mathematics performance (Table 5). The findings are interpreted and hence discussed accordingly.

Table 5. Correlation between Educational Qualification and Mathematics Performance.

\begin{tabular}{lll}
\hline & & Mathematics Performance \\
\hline Teacher & Pearson Correlation & .490 \\
Educational & Sig. (2-tailed) & .005 \\
Qualification & $\mathrm{N}$ & 31 \\
\hline
\end{tabular}

*. Correlation is significant at the 0.05 level (2-tailed).

The study revealed that the relationship between teacher educational qualification and mathematics performance was positive, strong and statistically significant $(\mathrm{r}=0.490 ; \mathrm{p}<$ 0.05). From the study findings, it was observed that the individual teachers' education contributes to the level of output and subsequent student performance in the subject matter.

\subsubsection{Relationship BetweenTeacher Training and Mathematics Performance}

In this section, the results of correlation analysis between teacher training and mathematics performance is analyzed, interpreted and hence discussed accordingly (Table 6). 
Table 6. Correlation between Teacher Training \& Mathematics Performance.

\begin{tabular}{lll}
\hline & & Mathematics Performance \\
\hline \multirow{2}{*}{ Teacher } & Pearson Correlation & .313 \\
Training & Sig. (2-tailed) & .008 \\
& N & 31 \\
\hline
\end{tabular}

*. Correlation is significant at the 0.05 level (2-tailed).

The study also revealed that the relationship between teacher training and mathematics performance was positive and statistically significant $(\mathrm{r}=0.313 ; \mathrm{p}<0.05)$. The study findings indicate that the quality of pre-service teacher training and the level of in-service training significantly influence the student achievement and school performance in KCSE.

\subsubsection{Relationship BetweenTeacher Experience and Mathematics Performance}

This section outlines the results of correlation analysis between teacher experience and mathematics performance (Table 7) with the findings interpreted and further discussed accordingly.

Table 7. Correlation between Teacher Experience \& Mathematics Performance.

\begin{tabular}{lll}
\hline & & Mathematics Performance \\
\hline \multirow{2}{*}{ Teacher } & Pearson Correlation & .361 \\
Experience & Sig. (2-tailed) & .046 \\
& $\mathrm{~N}$ & 31 \\
\hline
\end{tabular}

**. Correlation is significant at the 0.05 level (2-tailed).

The study further indicated that the relationship between teacher experience and mathematics performance was positive and statistically significant $(r=0.361 ; p<0.05)$. The study findings indicated that the level of teachers' experience in handling the KCSE candidate class significantly affects the performance of the students and hence the public secondary schools.

\subsubsection{Relationship BetweenTeacher Competence and Mathematics Performance}

This study assessed how teacher competence influenced KCSE performance in mathematics by the public secondary schools. Table 8, 9 and 10 show the results of the regression analysis.

Table 8. Model Summary.

\begin{tabular}{lllll}
\hline Model & R & R Square & $\begin{array}{l}\text { Adjusted R } \\
\text { Square }\end{array}$ & $\begin{array}{l}\text { Std. Error of } \\
\text { the Estimate }\end{array}$ \\
\hline 1 & $.550^{\mathrm{a}}$ & .302 & .225 & .42529 \\
\hline
\end{tabular}

A. Predictors: (Constant), Teacher Experience, Teacher Training, Teacher Educational Qualification

Table 8 outlines the results of coefficient of determination $\left(\mathrm{r}^{2}\right)$ and correlation coefficient $(\mathrm{R})$. The results of $\left(\mathrm{r}^{2}=0.302\right)$ and $(\mathrm{R}=0.550)$ reflected a positive strong correlation between the teacher competence and mathematics performance

Table 9. ANOVA.

\begin{tabular}{lllllll}
\hline \multicolumn{2}{l}{ Model } & $\begin{array}{l}\text { Sum of } \\
\text { Squares }\end{array}$ & Df & $\begin{array}{l}\text { Mean } \\
\text { Square }\end{array}$ & F & Sig. \\
\hline \multirow{3}{*}{$1 \quad$ Regression } & 2.115 & 3 & .705 & 3.898 & $.020^{\mathrm{b}}$ \\
& Residual & 4.884 & 27 & .181 & & \\
\hline & Total & 6.999 & 30 & & & \\
\hline
\end{tabular}

A. Dependent Variable: Mathematics Performance

B. Predictors: (Constant), Teacher Experience, Teacher Training, Teacher Educational Qualification

Table 9 presents the findings of analysis of variance (ANOVA). The analysis indicated that the teacher competence had significant effect on mathematics performance of public secondary schools $(\mathrm{F}=3.898 ; \mathrm{p}<0.05$ at $95 \%$ degree of confidence. These findings were based on the use of teacher competence to enhance the respective schools' KCSE performance in mathematics.

Table 10. Results of Regression Analysis.

\begin{tabular}{|c|c|c|c|c|c|}
\hline \multicolumn{6}{|l|}{ Coefficients $^{\mathrm{a}}$} \\
\hline & \multicolumn{2}{|c|}{ Unstandardized Coefficients } & \multirow{2}{*}{$\begin{array}{l}\text { Standardized Coefficients } \\
\text { Beta }\end{array}$} & \multirow{2}{*}{$\mathbf{t}$} & \multirow{2}{*}{ Sig. } \\
\hline & B & Std. Error & & & \\
\hline (Constant) & 1.373 & 1.057 & & 1.299 & .205 \\
\hline Teacher Educational Qualification & .265 & .123 & .381 & 2.157 & .040 \\
\hline Teacher Training & .236 & .229 & .174 & 1.033 & .031 \\
\hline Teacher Experience & .209 & .220 & .169 & .951 & .035 \\
\hline
\end{tabular}

a. Dependent Variable: Mathematics Performance

The outcomes of the regression analysis (Table 10) were interpreted using the following regression equation:

$$
\mathrm{Y}=\mathrm{a}+\beta_{1} \mathrm{C}_{1}+\beta_{2} \mathrm{C}_{2}+\beta_{3} \mathrm{C}_{3}+\check{\mathrm{e}}
$$

where $\mathrm{Y}, \mathrm{C}_{1}, \mathrm{C}_{2}$ and $\mathrm{C}_{3}$ represented mathematics performance, teacher educational qualification, teacher training and teacher experience respectively. The results were interpreted as follows: $\mathrm{Y}=1.373+0.265 \mathrm{C}_{1}+0.236 \mathrm{C}_{2}+$ $0.209 C_{3}$. Based on the regression analysis, the study findings thus indicated that mathematics performance by the public secondary schools significantly influenced by 0.265 teacher educational qualification, 0.236 teacher training and 0.209 teacher experience respectively.

\section{Summary of Findings, Conclusions \& Recommendations}

\subsection{Summary of Findings}

This section outlines the major findings of the study in 
tandem with each and every specific objective stated in chapter one.

\subsubsection{Summary of Teacher Educational Qualification}

Based on the study findings, the surveyed institutions strongly indicated that exceptional teacher education is necessary for enhancing the teachers' understanding of the subject matter and skills in disseminating mathematical content to secondary school learners. The respondents also revealed that fresh graduates with diplomas and undergraduate degrees are not better off at producing top grades in mathematics as opposed to their more experienced colleagues. In addition, the study found out that teachers with masters and above qualifications do not deliver any better results in KCSE examinations just like it was observed by [28] and [9]. Besides, it emerged that government policies on raising college entry requirements for teacher trainees and qualifications of teachers effectively improves the overall school performance and the respondents strongly had confidence in 8.4.4 system and thus local teacher training institutions and universities for producing competent teachers as opposed to the foreign institutions.

\subsubsection{Summary of Teacher Training}

According to the findings of the study, the surveyed respondents concurred that pre-service training for mathematics teachers in tertiary institutions of learning is good for laying strong foundation for the delivery of math content and that through in-service trainings, teaching skills for disseminating mathematical content at secondary school level are further enhanced. In addition, the respondents also indicated that by taking professional development courses, serving teachers are able to effectively implement the secondary school curriculum and hence enhance student achievement in mathematics as evidenced in [33]. Besides, the study findings further revealed that SMASSE trainings equips teachers with skills to enable them properly use teaching innovations for problem solving and that teachers who participate in SMASSE program yield improved school mean scores in mathematics in KCSE examinations. This was similar to the observations made in a study done by [23] on the effectiveness of SMASSE training program on KCSE performance in mathematics.

\subsubsection{Summary of Teacher Experience}

The study findings revealed that some of the subject teachers' teaching ability is very high over the first few years after taking up the teaching job, but declines year by year of service while other respondents indicated a contrary opinion. This further implied that teacher effectiveness varies from individual to individual and that not all teachers exhibit diminishing performance in KCSE examinations as time goes. The study also indicated that the surveyed respondents contended that the experienced mathematics teachers produce higher grades than the fresh college graduates and that inexperienced teachers coming from teacher education programs that last over long periods are not as efficient as the experienced teachers. Besides, the study findings further indicated that teaching experiences increase teacher effectiveness in delivering mathematical content to the learner and that teacher experience alone has no significant effect on learner achievement in the subject matter.

\subsubsection{Summary of Mathematics Performance}

Going by the study findings, it emerged that the schools' overall performance in mathematics depends on both teacher and student input. The study also shows that gender disparity persists in student performance in mathematics despite emphasis on teacher quality. Moreover, the researcher noted from the study findings that motivated teachers inspire better student performance in mathematics and that school performance in mathematics depends on who the subject teacher is and the individual teacher's professional characteristics. However, some of the respondents revealed that teacher performance in content delivery depends on students' scores in mathematics while others indicated a contrary opinion.

\subsection{Conclusions}

The conclusions made in this section were in context of the objectives of the study.

\subsubsection{Teacher Educational Qualification and Mathematics Performance}

The study revealed that the relationship between teacher educational qualification and mathematics performance was positive, strong and statistically significant. From the study findings, it was observed that the individual teachers' education standards contribute to the level of output and subsequent student performance in the subject matter. This implied that well educated teachers deliver instructional content more effectively and yield top quality results in national examinations.

\subsubsection{Teacher Training and Mathematics Performance}

The study further indicated that the relationship between teacher training and mathematics performance was positive and statistically significant. The study findings indicate that the quality of pre-service teacher training and the level of inservice training significantly influence the student achievement and school performance in KCSE. This implies that the quality of training given to teacher trainees has significant effect on their ability to perform at their work and in their respective duties. Moreover, the study indicated that for teachers to be more effective in delivering instruction, they need to update their skills by participating in workrelated trainings.

\subsubsection{Teacher Experience and Mathematics Performance}

The study further indicated that the relationship between teacher experience and mathematics performance was positive and statistically significant. The findings implied that the level of teachers' experience in handling the KCSE candidate class significantly affects the performance of the students and hence the public secondary schools. As such, it 
was observed that more experienced teacher deliver better results than the inexperienced or less experienced teachers.

\subsection{Recommendations}

The recommendations made in this study were based on the study findings in relation to the existing literature. According to the findings presented in the previous chapter, the following recommendations were imperative: first, teacher training institutions should invest more in technology and other infrastructure so as to enhance teacher effectiveness and innovativeness for better content delivery and performance; secondly, teacher training should focus more on the teacher trainee skill development rather than merely emphasizing on theoretical approach to learning. In addition, mathematics subject teachers should be encouraged and be facilitated to participate in SMASSE trainings and other in-service trainings to enhance their competence at work. Lastly, the teachers' employer (TSC) and other education stakeholders should purpose to develop each subject teacher's expertise, capabilities and potential to enhance better mathematics performance.

\subsection{Suggestions for Further Studies}

This study provided a detailed analysis of the influences of teacher competence on mathematics performance of public secondary schools in Nyatike sub-county. The study only focused on teacher educational qualification, teacher training and teacher experience. It is important that further research is done to assess implications of the teacher competence on the competitive performance of the learner in institutions of higher learning and subsequently in employment.

\section{References}

[1] Abe, T. O. (2014). The Effect of Teachers' Qualifications on Students' Performance in Mathematics. Sky Journal of Educational Research. Vol. 2(1), pp. 010-014.

[2] ADEA (2005). Mathematics and Science. Innovations in the Classroom. Assistance for the development of education in Africa.

[3] Amunga, J. K., \& Musasia, A. M. (2011). Disparities In Mathematics Achievement Among Secondary Schools. Problems of Education in the 21st Century, Vol. 28, pp. 8-11.

[4] Andrew, M., \& Schwab, R. L. (1995). Has reform in teacher education influenced teacher performance? An outcome assessment of graduates of eleven teacher education programs. Action in Teacher Education, vol. 17, pp 43-53.

[5] Bekić, D. \& Zlatić, L. (2010). Teacher education and training system in Serbia, in: Karras, K. G. \&Wolhuter, C. C. (eds.). International Handbook on Teacher EducationWorldWide: Training, Issues and Challenges for Teachers Profession, Athens: Atropos Edition.

[6] Bjekić, D., Zlatić, L., \& Čaprić, G. (2008). Reserach procedure of the pre-service and in service education of communication competent teachers, in: Hudson, B., Zgaga, P. (eds.). Teacher Education Policy in Europe: A Voice of
Higher Education Institutions, Monograph of Journal of Research in Teacher Education, Umea: Faculty of Teacher Education - University of Umea, 245-264.

[7] Bjekić, D. (2000). Teaching effectiveness and teachers'empathy (Uspesnost u nastaviiempatijanastavnika), Psihologija, 33(3-4), 707-724,

http://scindeksclanci.nb.rs/data/pdf/00485705/2000/004857050003499B.pdf

[8] Bodroški-Spariosu, B. (2010): Basic dimensions of educational system quality (Osnovnedimenzijekvalitetaobrazovnihsistema), Nastavaivaspitanje, 4, 618-632.

[9] Darling-Hammond, L. (1999). Teacher quality and student achievement: A review of state policy evidence. Seattle, WA: Center for the Study of Teaching and Policy, University of Washington.

[10] Darling-Hammond, L. (2000). How teacher education matters. Journal of Teacher Education 51(3), 166-173.

[11] Darling-Hammond, L., Berry, B., \&Thoreson, A. (2001) Does Teacher Certification Matter? Evaluating the Evidence. Educational Evaluation and Policy Analysis. 23 (1), 57-77.

[12] Denton, J. J., and Peters, W. H. (1988). Program assessment report: Curriculum evaluation of a non-traditional program for certifying teachers. Texas A \&M University, College Station, TX.

[13] Donaldson, T. A. (1995). "The Stakeholder Theory of the Corporation: Concepts, Evidence, and Implications. Academy of Management in Organization, vol. 20(1), pp. 65-91.

[14] Elliot, M. (1998) School finance and opportunities to Learn: Does money well spent enhance students achievement? Sociology of Education, 71, 223-245.

[15] Evertson, C. M., Hawley, W. D., \& Zlotnik, M. (1985). Making a difference in educational quality through teacher education. Journal of Teacher Education, 36 (3), 2-13.

[16] Goeke, J. K. M. (2013). Effects of Math Benchmarking on Students at the Elementary Level. Northwest Missouri State University Missouri. Unpublished Research Paper. p. 1-27.

[17] Golafshani, N., (2003) Understanding Reliability and Validity in Qualitative Research. The Qualitative Report, 8 (4).

[18] Hanushek, E. A., Kain, J. F., \& Rivkin, S. G. (1998). Teachers, Schools and Academic Achievement. Working Paper 6691. NBER Working Paper Series. Cambridge MA: National Bureau of Economic Research.

[19] Hill, C. J., Bloom, H. S., Black, A. R., \& Lipsey, M. W. (2007). Empirical Benchmarks for Interpreting Effect Sizes in Research. Child Development Perspectives, vol. 2(3), pp. 172177.

[20] Hill, H. C., Rowan, B., \& Ball, D. L. (2010). Effects of Teachers' Mathematical Knowledge for Teaching on Student Achievement. American Educational Research Journal, pp. 65-79.

[21] Irungu, M. N., \& Mugambi, Mercy. (2013). Evaluation of Strengthening of Mathematics and Science in Secondary Education (SMASSE) Program. A Case Study of Murang'aSouth District, Kenya. International Journal of Education, Learning \& Developemnt, Vol. 1(1), pp. 46-60. 
[22] Kajuru, Y. K., Ibrahim, M. O. \& Olaleye, O. O. (2015). Effects of Teachers' Qualification and Competency on Performance in Further Mathematics Among Senior Secondary School Students in Kaduna State, Nigeria. International Journal of Educational Research and Information Science, vol. 2 (4), pp. 93-97.

[23] Kenya National Examinations Council. (2016). The 2015 Kenya Certificate of Secondary Education (KCSE) Examination Essential Statistics. pp.1-20.

[24] Kiige, M. J., \& Atina, J. O. (2016). The Effectiveness of SMASSE Teacher Training Programme on KCSE Performance in Mathematics and Chemistry Subjects in KikuyuDistrict, Kenya. Journal of Education and Practice, Vol. 7(6), 2016.

[25] Klitgaard, R. E., \& Hall, G. R. (1974). Are there unusually effective schools? Journal of Human Resources, vol. 10 (3), 90-106.

[26] Kosgei, A., Mise, J. K., Odera, O., \& Ayugi, M. E. (2013). Influence of Teacher Performance on Students Academic Achievement Among Secondary schools.Journal of Education \&Practice.vol. 4 (3), pp. 76-83.

[27] Kothari, C. R. (2004). Research Methodology: Methods and Techniques $\left(2^{\text {nd }}\right.$ Ed.) NewDelhi: New Age International $(\mathrm{P})$ Limited.

[28] Marinkovic, S., Bjekic, D., \& Zlatic, L. (2012). Teachers' Competence as teh Indicator of the Quality and Condition of Education. University of Kragujevac, Serbia, 1-16.

[29] Monk, D. H. (1994). Subject matter preparation of secondary mathematics and science teachers and student achievement. Economics of Education Review, 13(2), 125-145.

[30] Moraga, G. Y. (1983). Evaluation of 1982 in-service of secondary school teacher education programmes in Ethiopia. Department of teacher education, Ministry of Education, Ethiopia.

[31] Murnane, R. J., \& Phillips, B. R. (1981). Learning by doing, vintage and selection: Three pieces of the puzzle relating teacher experience and teaching performance. Economics of Education Review, 1(4), 453-465.

[32] Musau, L. M., \& Abere, M. J. (2015). Teacher Qualification and Students' Academic Performance in Science Mathematics and Technology Subjects in Kenya.International Journal of Education Administration and Policy Studies. Vol. 7(3), pp. 83-89.

[33] Myrberg, E., \& Ros, N, M. (2003). Social selection into independent schools in Sweden. Results from PIRLS 2001. Gothenburg: Department of Education.

[34] Naoreen, B., Aslam, S., Nausheen, R., \& Arshad, M. (2011). Impact of In-Service Teacher Training on Students' Learning Achievement in Mathematics. International Conference on Social Science and Humanity IPEDR vol. 5(2). pp. 168-174.

[35] Nui. N. W., \& Nyacomba, A. (2006). SMASSE Project accessed from www.criced.tsukuba.ac.jp/math/sympo_2006/nui.pdf on 14th April 2013Ornstein, A. C., \& Hunkins, F. P. (2002), Curriculum, foundations, principles and issues. United States.
[36] Odhiambo, M. N., \& Toili, W. W. (2013). The Implications of the Use ofElectricalCalculators on Students' Performance in Mathematics in Seondary Schools in Kenya. African Journal of Education and Technology, Vol. 3(1), pp. 10-17.

[37] Odumbe, G. A., Simatwa, E. M. W., \& Ayodo, T. M. O. (2015). Factors Influencing Student Academic Performance in Day-Secondary Schools in Kenya. A case Study of MigoriSub County. Greener Journal of Educational Research, Vol. 5(3): 078-097, http://doi.org/10.15580/GJER.2015.3.071815099.

[38] OECD (2004). Learning for tomorrow's world. First results from PISA 2003: OECD

[39] Okumbe, J. A. (1999). Education Management: theory and practice. Nairobi: University Press.

[40] Onasanya, S. A., \& Abduliahi, O. E. (2010). Effect of Teacher Effectiveness on Kawara State Secondary School Students' Achievement in Mathematics. Madwell Journals, vol. 5(4), pp. 286-292.

[41] Parker-Stanford, C. (2014). Good English Teachers Improve Math Scores for Students.Stanford University.

[42] Passos, A. F. (2009). A Comparative Analysis of Teacher Competence and Its Effect on Pupil Performance in Upper Primary Schools in Mozambique and other SACMEQ Countries. University of Pretoria. Unpublished PHD Thesis, pp. 38-45.

[43] Rice, J. K. (2010). The Impact of Teacher Experience: Examining the Evidence and Policy Implications. National Center for Analysis of Longitudinal Data in Education Research. Brief 11. pp. 1-8.

[44] Rosenholtz, S. J. (1986). The organizational context of teaching. In Learning to Teach.University of Illinois at Champaign-Urbana.

[45] Sapsford, R., \& Jupp, V., (2006) Data Collection and Analysis. New Delhi: SAGE publishers.

[46] Saunders, S. (2008). Measuring and applying the PAKSERV service quality construct: Evidence from a South African cultural context. Manag. Serv. Qual. 18(5), 442-456.

[47] Schwarz, G. (2013). Response Rate in European Business Tendency Surveys. Australian Institute of Economic Research, $1-54$.

[48] SMASSE Project Report (2007). Report on the survey of impact of the SMASSE INSET in Kenya. SMASSE, Nairobi.

[49] Trinder, J. C. (2008). Competency Standards - A Measure of the Quality of a Workforce. The International Archives of the Photogrammetry, Remote Sensing and SpatialInformation Sciences.vol. 37(B6a), pp. 165-168.

[50] Wayne, A. J., \& Youngs, P. (2003). Teacher Characteristics and Student Achievement Gains: A Review. Review of Educational Research, 73 (1) 89-122.

[51] Weiers, R. M., (2011) Introductory Business Statistics. SouthWestern: Cengage Learning.

[52] Zuzovsky, R. (2003). Teachers' Qualifications and their Impact on Student Achievement: Findings from TIMSS 2003 data for Israel. Center for Science and Technology Education. Tel Aviv University, Tel Aviv, Israel. Pp. 37-62. 